\title{
Effects of continuous and increasing lipopolysaccharide infusion on basal and stimulated metabolism in lactating Holstein cows
}

\author{
E. A. Horst, S. K. Kvidera, M. J. Dickson, C. S. McCarthy, E. J. Mayorga, M. AI-Qaisi, H. A. Ramirez, \\ A. F. Keating, and L. H. Baumgard* \\ Department of Animal Science, lowa State University, Ames 50011
}

\section{ABSTRACT}

Experimental objectives of this study were to characterize the systemic and intracellular metabolic response to continuous lipopolysaccharide (LPS) infusion in mid-lactation Holstein cows $(169 \pm 20 \mathrm{~d}$ in milk; 681 $\pm 16 \mathrm{~kg}$ of body weight). Following $3 \mathrm{~d}$ of acclimation, cows were enrolled in 2 experimental periods $(\mathrm{P})$. During P1 $(3 \mathrm{~d})$, cows were fed ad libitum and baseline data were collected. In P2 $(8 \mathrm{~d})$, cows were assigned to 1 of 2 treatments: (1) saline-infused and pair-fed (CON-PF; i.v. sterile saline at $40 \mathrm{~mL} / \mathrm{h} ; \mathrm{n}=5$ ) or (2) LPS-infused and fed ad libitum (LPS-AL; Escherichia coli $\mathrm{O} 55$ :B5 at $0.017,0.020,0.026,0.036,0.055,0.088$, 0.148 , and $0.148 \mu \mathrm{g} / \mathrm{kg}$ of body weight per hour for $\mathrm{d}$ 1 through 8 , respectively; $\mathrm{n}=6$ ). During P2, CONPF cows were pair-fed to LPS-AL cows to eliminate confounding effects of dissimilar nutrient intake. Blood samples were collected on $\mathrm{d} 1$ and 2 of $\mathrm{P} 1$ and $\mathrm{d} 1,3,5$, and 7 of P2. Following the P2 d 7 a.m. milking, adipose tissue, skeletal muscle, and liver biopsies were collected for reverse transcription quantitative PCR and Western blot analysis. To assess whole-body nutrient trafficking, an i.v. glucose tolerance test (GTT) was performed following the a.m. milking on P2 d 8; $4 \mathrm{~h}$ after the GTT, cows received an epinephrine challenge. During $\mathrm{P} 2$, there were no treatment differences in circulating glucose. Relative to P1, CON-PF cows had or tended to have decreased plasma $\beta$-hydroxybutyrate and insulin (29 and 47\%, respectively) during P2, whereas neither variable changed in LPS-AL cows, leading to an overall increase in $\beta$-hydroxybutyrate and insulin (41 and $140 \%$, respectively) relative to CON-PF cows. Circulating nonesterified fatty acids were increased from $\mathrm{d} 1$ to 3 and subsequently decreased from d 3 to 7 in cows from both treatments. Blood urea nitrogen gradually decreased in CON-PF cows and increased in LPS-AL

Received August 30, 2018.

Accepted November 21, 2018.

*Corresponding author: baumgard@iastate.edu cows from d 1 to 5 of $\mathrm{P} 2$, resulting in an overall $25 \%$ increase in LPS-AL versus CON-PF cows. In response to the GTT, the glucose and insulin area under the curve were increased 33 and $56 \%$, respectively, in LPSAL compared with CON-PF cows; changes reflective of whole-body insulin resistance. However, protein abundance of insulin signaling markers within muscle, liver, and adipose tissue were similar between treatments. There were no observable treatment differences in the glucose or nonesterified fatty acids response to the epinephrine challenge. No treatment differences were observed in hepatic mRNA abundance of key gluconeogenic or lipid export enzymes. In conclusion, chronic LPS exposure altered multiple parameters of basal and stimulated metabolism, but did not appear to affect the molecular machinery evaluated herein.

Key words: inflammation, insulin, lipopolysaccharide

\section{INTRODUCTION}

Inflammation is energetically expensive (Johnson, 2012; Iseri and Klasing, 2013; Kvidera et al., 2017), impedes optimal production, and is an economic and animal welfare concern. Immunoactivation begins with leukocyte recognition of pathogen-associated molecular patterns (PAMP), culminating in transcription and production of inflammatory cytokines. Upon activation, most immune cells become obligate glucose utilizers via a metabolic shift from oxidative phosphorylation to aerobic glycolysis, a process known as the "Warburg effect" (Palsson-McDermott and O'Neill, 2013). During immune activation, a variety of coordinated metabolic adjustments occur, including hyperglycemia or hypoglycemia (depending upon the stage and severity of infection; Waldron et al., 2003; Kvidera et al., 2017), increased circulating insulin and glucagon (Waldron et al., 2003), skeletal muscle catabolism (Wannemacher et al., 1980), and hypertriglyceridemia (Filkins, 1978; Wannemacher et al., 1980; Lanza-Jacoby et al., 1998; McGuinness, 2005). Further, milk synthesis is reduced (Lohuis et al., 1988; Waldron et al., 2003; Gröhn et al., 2004) and skeletal muscle and adipose tissue become 
insulin insensitive (Lang et al., 1990) during immune activation. Collectively, the aforementioned changes in endocrine signaling and nutrient trafficking are presumably strategies to ensure adequate glucose delivery to activated immune cells. However, the PAMP response is spatially dependent and varies in magnitude, as repeated or continuous exposure to endotoxin causes hyporesponsiveness (i.e., tolerance; Beeson, 1947). Thus, interpreting PAMP-induced metabolic responses requires putting infection dynamics into temporal context.

Inflammation is often experimentally modeled by administering a single or repeated bolus of LPS, a cellwall component of gram-negative bacteria that elicits a well-described and robust immune response (van Miert and Frens, 1968; Lohuis et al., 1988). However, natural infection likely comprises a persistent, dynamic LPS exposure. Therefore, key knowledge gaps remain in distinguishing how accurate single or repeated LPS boluses mimic chronic, naturally occurring pathogen exposure. Human data suggest continuous LPS infusion prompts a less aggressive, but more sustained release of inflammatory mediators; ostensibly a more appropriate model of chronic inflammation than an acute bolus (Taudorf et al., 2007). Having a better understanding of how constant LPS infusion affects immunometabolism is critical to developing strategies to minimize production losses in naturally immunoactivated farm animals. Therefore, experimental objectives were to characterize the effect of continuous and exponentially increasing LPS infusion on basal and stimulated metabolism at the circulating (basal and stimulated) and molecular level to better understand how chronic immunostimulation affects nutrient partitioning and overall performance.

\section{MATERIALS AND METHODS}

\section{Animals and Experimental Design}

Iowa State University Institutional Animal Care and Use Committee approved all procedures involving animals. Twelve nonpregnant lactating Holstein cows (169 \pm 20 DIM; $681 \pm 16 \mathrm{~kg}$ of BW; parity $3.1 \pm 0.4$ ) were used and housed in individual box-stalls $(4.57 \times 4.57$ m) at the Iowa State University Dairy Farm throughout the entire experiment. Nonpregnant mid-lactation cows were selected in an attempt to reduce the variability in basal inflammation and to minimize the variation in nutrient partitioning (metabolic and endocrine) commonly observed in transition and heat-stressed cows. Cows were allowed to acclimate for $3 \mathrm{~d}$, during which bilateral jugular catheters were implanted, and were then enrolled in 2 experimental periods. Period 1 (P1) lasted $3 \mathrm{~d}$ and served as the baseline (data generated for covariate analysis) for period 2 (P2). Period 2 lasted $8 \mathrm{~d}$, during which cows received 1 of 2 treatments: (1) control (CON-PF; sterile saline infused i.v. continuously via the jugular vein at a rate of $40 \mathrm{~mL} / \mathrm{h} ; \mathrm{n}=$ 5) or (2) LPS-infused (LPS-AL; 0.017, 0.020, 0.026, $0.036,0.055,0.088,0.148$, and $0.148 \mu \mathrm{g} / \mathrm{kg}$ of BW per hour for d 1 through 8, respectively; $\mathrm{n}=6$; Figure 1). The LPS solution was i.v. infused continuously at a known and adjustable rate utilizing a modular pump (Deltec 3000, Deltec Inc., St. Paul, MN). The increasing LPS dose and daily infusion rate were selected based on data from a similar experimental design utilizing pigs (Kvidera et al., 2016b; Huntley et al., 2017). A stock solution of LPS (Escherichia coli O55:B5; Sigma Aldrich, St. Louis, MO) was created at a concentration of $300 \mu \mathrm{g} / \mathrm{mL}$, passed through a $0.2-\mu \mathrm{m}$ sterile syringe filter (Thermo Fisher Scientific, Waltham, MA), and stored in a sterile glass bottle $24 \mathrm{~h}$ before P2. Each day, the amount of stock solution needed for each cow's daily dose was calculated and injected into a 1-L bottle of sterile saline. The i.v. infusion system was incubated overnight with LPS solution $(3 \mu \mathrm{g} / \mathrm{mL}) 1 \mathrm{~d}$ before infusion initiation to saturate potential plastic LPS binding sites. One cow from the CON-PF treatment was removed from the experiment due to health issue and its data were not included in the final data set.

Control animals were pair-fed (PF) with the LPStreated cows to eliminate the confounding effects of dissimilar nutrient intake, as we have previously described (Wheelock et al., 2010). In brief, feed intake was averaged for each cow and used as a baseline. During P2, the decrease in feed intake in LPS-infused cows was calculated every day as a percentage of their P1 feed intake. The percentage of feed intake reduction was averaged for all LPS-infused cows per day of LPS infusion and applied individually to the baseline of each cow in the PF treatment for that respective day. All cows were individually fed a TMR once daily at $0800 \mathrm{~h}$, and orts were recorded before feeding. The TMR (consisting primarily of corn silage) was formulated by Dynamic Nutrition Systems (Pierz, MN) to meet or exceed the predicted requirements of energy, protein, minerals, and vitamins (NRC, 2001; Table 1). Reduced daily feed intake by LPS-treated cows during P2 was determined as a percentage of their mean daily ad libitum intake during P1. To facilitate space constraints and to allow for PF calculations and implementation, control cows were $9 \mathrm{~d}$ behind LPS cows in the experimental protocol. Throughout the experiment, cows were milked twice daily at 0600 and $1800 \mathrm{~h}$, and yields were recorded at each milking. Body weights were recorded on d 1 of acclimation and were used to calculate LPS dosage. 
Table 1. Ingredients and composition of $\operatorname{diet}^{1}$

\begin{tabular}{lr}
\hline $\begin{array}{l}\text { Item (\% of DM, } \\
\text { unless noted) }\end{array}$ & Value $^{2}$ \\
\hline Ingredient & \\
Corn silage & 32.53 \\
Corn gluten feed & 19.61 \\
Alfalfa hay & 12.80 \\
CP mix & 11.09 \\
Ground corn & 8.76 \\
Cottonseed & 5.10 \\
Soybean meal & 4.75 \\
Molasses & 2.43 \\
Expeller soybean meal & 0.89 \\
Straw & 2.04 \\
Chemical analysis & \\
Starch & 22.86 \\
CP & 16.95 \\
NDF & 31.09 \\
ADF & 20.28 \\
NE (Mcal/kg of DM) & 1.61 \\
\hline
\end{tabular}

${ }^{1}$ Values represent an average of ration nutrient summary reports collected throughout the trial. Diet moisture averaged $52.49 \%$.

${ }^{2}$ Average nutrient levels: $5.02 \%$ fat, $0.91 \% \mathrm{Ca}, 0.47 \% \mathrm{P}, 0.36 \% \mathrm{Mg}$, $0.23 \% \mathrm{~S}, 1.32 \% \mathrm{~K}, 0.53 \% \mathrm{Na}, 0.59 \% \mathrm{Cl}, 69.39 \mathrm{mg} / \mathrm{g}$ of Zn, $38.09 \mathrm{mg} / \mathrm{g}$ of $\mathrm{Mn}, 3.02 \mathrm{mg} / \mathrm{g}$ of $\mathrm{Fe}, 11.61 \mathrm{mg} / \mathrm{g}$ of $\mathrm{Cu}, 0.65 \mathrm{mg} / \mathrm{g}$ of $\mathrm{Co}, 0.28$ of $\mathrm{mg} / \mathrm{g} \mathrm{Se}, 0.65 \mathrm{mg} / \mathrm{g}$ of I, $6005.6 \mathrm{IU} / \mathrm{kg}$ of vitamin $\mathrm{A}, 477.9 \mathrm{IU} / \mathrm{kg}$ of vitamin $\mathrm{D}$, and $15.7 \mathrm{IU} / \mathrm{kg}$ of vitamin $\mathrm{E}$.

${ }^{3} 34.06 \%$ Soybean meal, $15.91 \%$ Ca carbonate, $15.89 \%$ blood meal, 10.21\% Sodium Biocarb, 9.08\% MagnaPalm, 5.46\% Salt, 3.07\% Micro premix, $2.27 \%$ urea, $2.04 \%$ magnesium oxide, $0.68 \%$ Alimet, $0.58 \%$ Choice White Grease, 0.58\% Smartamine M, 0.10\% Rumensin, 0.04\% Biotin, and 0.02\% Zinpro 120 (Zinpro Corp., Eden Prairie, MN).
Plasma samples were collected daily at $0600 \mathrm{~h}$ during both P1 and P2. Whole blood was collected from a jugular catheter contralateral to the LPS-infusion catheter using EDTA as the anticoagulant $\left(\mathrm{K}_{2}\right.$ EDTA, BD Vacutainer, Franklin Lakes, NJ). Plasma was harvested following centrifugation at $1,500 \times g$ for $15 \mathrm{~min}$ at $4^{\circ} \mathrm{C}$ and subsequently frozen at $-20^{\circ} \mathrm{C}$ until analysis.

\section{Tissue Collection}

Liver, skeletal muscle, and tailhead subcutaneous adipose tissue biopsies were collected from all animals on d 7 of P2 following the morning milking. Briefly, biopsy sites were shaved clean, scrubbed with betadine, and sprayed with $70 \%$ alcohol. For liver collection, the area was locally anesthetized using $2 \%$ lidocaine (MWI Veterinary Supply Co., Glendale, AZ) before performing a percutaneous biopsy with a trocar. Before collection of adipose and muscle biopsies, a caudal epidural (25 $\mathrm{mg}$ of xylazine and $100 \mathrm{mg}$ of lidocaine hydrochloride) was administered. Tailhead subcutaneous adipose tissue was collected as previously described (Leury et al., $2003)$; in brief, an incision of 2 to $3 \mathrm{~cm}$ was made between the tailhead and tuber ischiadicum and adipose tissue was collected. For skeletal muscle collection, an incision of $\sim 5 \mathrm{~cm}$ was made in the hind limb semitendinosus and a sterile biopsy punch $(8 \mathrm{~mm}$, Miltex Inc.,

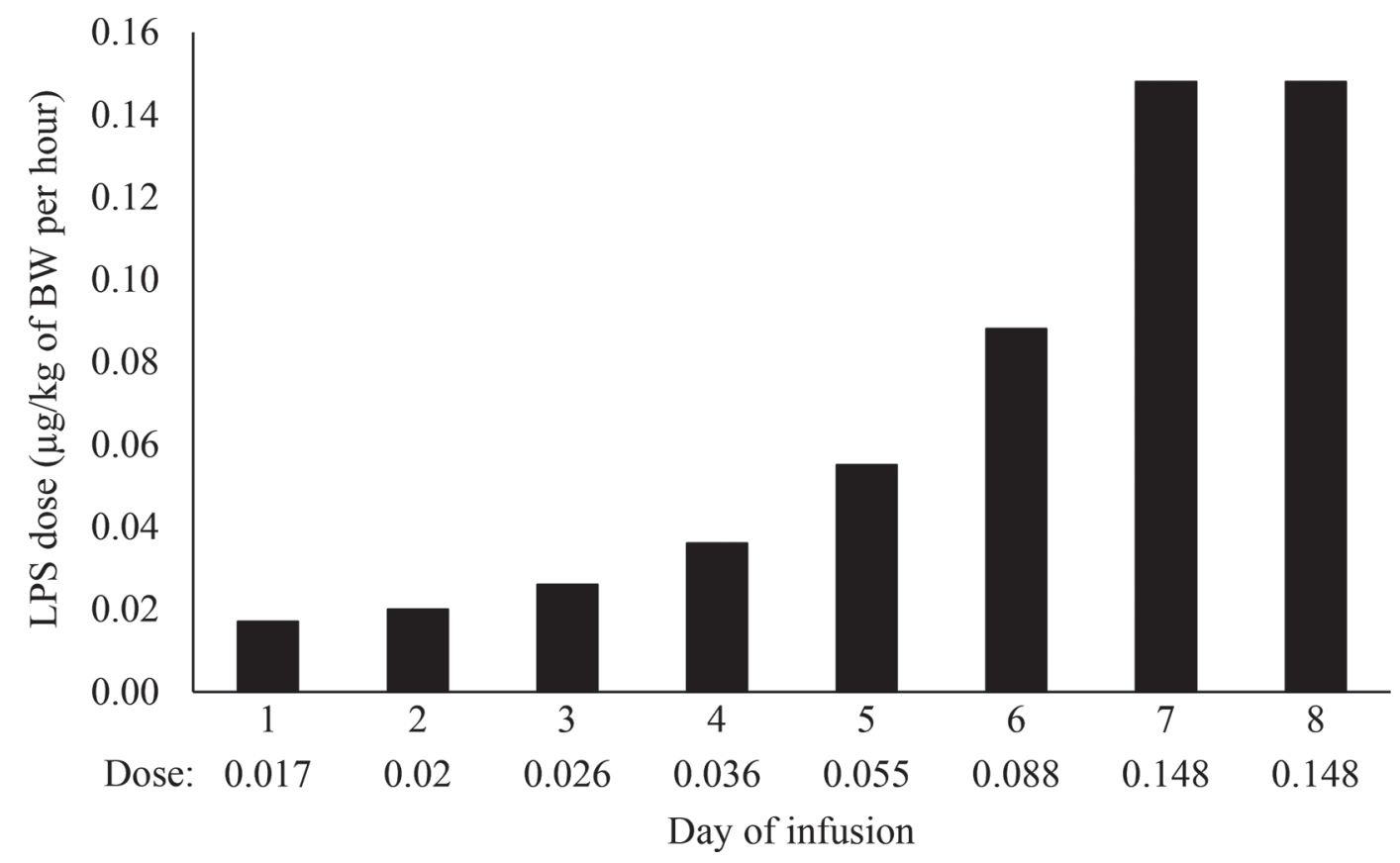

Figure 1. Daily dose schedule of LPS administered intravenously via a jugular catheter in LPS infused, ad libitum feed intake (LPS-AL) cows. Rate of infusion remained constant at $40 \mathrm{~mL} / \mathrm{h}$, whereas LPS solution concentration was adjusted to achieve the predetermined daily dose. Control cows were infused with sterile saline at a rate of $40 \mathrm{~mL} / \mathrm{h}$. 
York, PA) was used for collection of one tissue core. Following collection, adipose and muscle biopsy sites were sutured, cleaned with $70 \%$ isopropanol, and covered with an aerosol bandage (Allushield, Valley Vet, Maryville, KS). All tissue samples were snap-frozen in liquid nitrogen and stored at $-80^{\circ} \mathrm{C}$ until analysis.

\section{Metabolic Challenges}

For both metabolic challenges, feed was removed immediately before the challenge and was returned upon challenge conclusion. On d 8 of P2, a glucose tolerance test (GTT) was performed following the morning milking at $0600 \mathrm{~h}$. A $50 \%$ dextrose solution bolus (VetOne; MWI Veterinary Supply, Boise, ID) was administered at $0.25 \mathrm{~g} / \mathrm{kg}$ of BW via the jugular catheter, as previously described (Wheelock et al., 2010). Blood samples were collected at $-30,-20,-10,0,5,7.5,10,20,30$, 45,60 , and 90 min relative to glucose administration. Four hours after the conclusion of the GTT, an epinephrine challenge (EC; $1.4 \mu \mathrm{g} / \mathrm{kg}$ of BW; VetOne; MWI Veterinary Supply) was performed as previously described (Baumgard et al., 2002), and blood samples were collected $-30,-20,-10,2.5,5,7.5,10,20,30$, $45,60,90$, and 120 min relative to epinephrine administration. All blood samples were collected in disposable tubes containing EDTA as the anticoagulant (K2 EDTA, BD Vacutainer).

\section{RNA Isolation and Quantitative Reverse Transcription PCR}

Quantitative reverse transcription PCR was used to measure mRNA abundance of genes involved in gluconeogenesis and lipid oxidation and transport. In brief, total RNA was isolated from liver biopsies using a commercially available kit according to manufacturer's instructions (RNeasy Mini kit, Qiagen Inc., Valencia, CA; https://www.qiagen.com/us/shop/ sample-technologies/rna/total-rna/rneasy-mini-kit/ \#orderinginformation). The RNA was quantified using UV spectroscopy (ND-1000 spectrophotometer; $\lambda$ $=260 / 280 \mathrm{~nm}$; NanoDrop Technologies Inc., Thermo Fisher Scientific). Reverse transcription of RNA was performed using a Superscript III system (Invitrogen, Carlsbad, CA) and synthesized cDNA was stored at $-20^{\circ} \mathrm{C}$. Genes of interest were amplified with an Eppendorf mastercycler (Hauppauge, NY) using a QuantiTect SYBR Green PCR kit (Qiagen Inc.) with slight modifications. Primers were prepared by the Iowa State University DNA facility (Ames). Sequences for acylcoenzyme A oxidase 1 (ACOX1), apolipoprotein $\mathrm{A}-\mathrm{V}$ (APOA5), apolipoprotein 100B (APOB100), phospho- enolpyruvate carboxykinase 1 ( $P C K 1$ ), and glucose6-phosphatase catalytic subunit $(G 6 P C)$ were designed via NCBI primer blast (https://www.ncbi.nlm.nih.gov/ tools/primer-blast/). Each set of reactions was run with 2 sets of negative controls including water only and cDNA with Mastermix (Qiagen Inc.,) and omission of primers. Quantification of fold-change gene expression was performed using the $2^{-\Delta \Delta \mathrm{Ct}}$ method with ribosomal protein 15 (RPS15) used as the reference gene.

\section{Protein Extraction and Western Blotting}

Liver, skeletal muscle, and adipose tissue samples were immersed in tissue lysis buffer (Triton X-100, HEPES, $\mathrm{NaCl}$, glycerol, NaF, EDTA, SDS) containing protease and phosphatase inhibitors (Halt Protease \& Phosphatase Single-Use Inhibitor Cocktail 100×; 78442, Thermo Fisher Scientific), homogenized [via mortar and pestle or a Tissue Tearor 985370-395 homogenizer (BioSpec, Bartlesville, OK) followed by sonication], and subjected to centrifugation $(10,621 \times g$ for $15 \mathrm{~min}$ at $4^{\circ} \mathrm{C}$ ). Protein content of the supernatant was quantified using a bicinchoninic acid assay. Protein extract was mixed with Laemmli buffer, $\beta$-mercaptoethanol, and water and heated at $95^{\circ} \mathrm{C}$ for $5 \mathrm{~min}$. Samples were stored at $-20^{\circ} \mathrm{C}$ until use. Fixed amounts of protein were loaded onto precast SDS PAGE gels and transferred onto nitrocellulose membranes (iBLOT, Invitrogen). Verification of equal loading was determined using a Ponceau S stain. Membranes were blocked for 1 $\mathrm{h}$ at room temperature in 5\% BSA in PBS with Tween 20 (PBST) and incubated in diluted (5\% BSA/PBST or PBST only) primary antibody at $4^{\circ} \mathrm{C}$ overnight. Antibodies assessed were insulin receptor substrate-1 (IRS-1; 1:500 for adipose, 1:1,000 dilution for muscle and liver; Santa Cruz Biotechnology, Santa Cruz, CA), phosphorylated-IRS-1 (phosphor-IRS-1; Tyr 632; 1:500 for adipose, 1:1,000 dilution for muscle and liver; Santa Cruz Biotecnology), protein kinase B (Akt; 1:250 for adipose, 1:1,000 dilution for muscle and liver; Cell Signaling Technology, Danvers, MA), phosphorylatedAkt (phosphor-Akt; Thr 308; 1:250 for adipose, 1:500 dilution for muscle and liver; Cell Signaling Technology), and insulin receptor- $\beta$ (INSR- $\beta$; 1:250 for adipose, 1:1,000 for muscle, 1:500 for liver; Abbiotec, San Diego, $\mathrm{CA}$ ). Membranes were washed 3 times (10 min each) with PBST on the next day and incubated with the secondary antibody (anti-goat IgG, HRP-linked, Thermo Fisher Scientific; or anti-rabbit IgG, HRP-linked, Cell Signaling Technology) for $1 \mathrm{~h}$ at room temperature. Enhanced chemiluminescence (Signal Fire, Cell Signaling Technology) substrate was applied to the membrane in the dark and then imaged using a ChemiImager 5500 
(Alpha Innotech, San Leandro, CA) with AlphaEaseFC software (v3.03 Alpha Innotech) or exposed to x-ray film. Protein abundance was quantified as the mean gray value for each membrane using ImageJ software (National Institutes of Health, Bethesda, MD) and was normalized to Ponceau S images. Additionally, negative controls were run, including primary only, secondary only, and IgG with secondary antibody to ensure antibody specificity.

\section{Liver Triglyceride Content Analysis}

Portions of the liver samples $(\sim 5.0 \mathrm{~g})$ were weighed, dried for $18 \mathrm{~h}$ at $102^{\circ} \mathrm{C}$, and reweighed after cooling to determine liver moisture percentage. Hepatic triglyceride content was measured as previously described (Morey et al., 2011). A 20-mg liver sample was weighed and homogenized with $500 \mu \mathrm{L}$ of chilled PBS. The homogenate was then centrifuged at $8,000 \times g$ for $2 \mathrm{~min}$ at $4^{\circ} \mathrm{C}$. Free glycerol was immediately determined using $10 \mu \mathrm{L}$ of supernatant via enzymatic glycerol phosphate oxidase method (Sigma-Aldrich). An additional 300 $\mu \mathrm{L}$ of supernatant was removed and incubated with 75 $\mu \mathrm{L}$ of lipase (MP Biomedicals, Solon, $\mathrm{OH}$ ) at $37^{\circ} \mathrm{C}$ for $16 \mathrm{~h}$ before determining total glycerol using the same method. Free glycerol (before lipase digestion) was subtracted from total glycerol (after lipase digestion) to determine triglyceride content, and this was expressed as a percentage of wet weight of the original sample. The intra-assay (all samples ran on a single plate) coefficients of variation for free glycerol and total glycerol were 0.14 and $0.72 \%$, respectively.

\section{Measurement of Plasma Parameters}

Plasma glucose, insulin, nonesterified fatty acids (NEFA), BHB, L-lactate, and BUN were determined using commercially available kits according to manufacturers' instructions (glucose, Wako Chemicals USA Inc., Richmond, VA; insulin, Mercodia AB, Uppsala, Sweden; NEFA, Wako Chemicals USA; BHB, Pointe Scientific Inc., Canton, MI; L-lactate, Biomedical Research Service Center, Buffalo, NY; BUN, Teco Diagnostics, Anaheim, CA). The inter- and intra-assay coefficients of variation for glucose, insulin, NEFA, BHB, L-lactate, and BUN assays were 1.4 and 4.4\%, 5.9 and $5.2 \%, 2.2$ and $3.5 \%, 4.0$ and $5.7 \%, 9.7$ and $20.7 \%$, and 9.1 and $5.3 \%$, respectively. Intra-assay coefficients of variation were calculated from $\sim 40$ replicates/plate. Interassay coefficients of variation were calculated from 2 plates for glucose, insulin, NEFA, BHB, and L-lactate and from 5 plates for BUN.

\section{Calculations and Statistical Analyses}

Production and immunological data are reported elsewhere (Dickson et al., 2019). Metabolic responses to the GTT and EC were calculated as area under the curve (AUC) by linear trapezoidal summation between successive pairs of metabolite concentrations and time coordinates after subtracting baseline values. For the GTT, AUC was calculated through the 90- and 45-min samples for glucose and insulin, respectively. For the EC, AUC was calculated through the 60-min sample for both glucose and NEFA. The AUC data were analyzed using PROC MIXED (SAS Institute Inc., Cary, NC), with treatment as a fixed effect and cow as the random effect. Western blot and liver TAG content data were analyzed using a diagonal covariance structure with treatment as a fixed effect and cow as a random effect. Quantitative reverse transcription PCR data were analyzed using a paired $t$-test. For blood data, each animal's respective parameter was analyzed using repeated measures with an autoregressive covariance structure and the repeated effect was day of LPS administration and cow was the random effect. Each specific variable's prebolus value (when available) served as a covariate. Effects of treatment, day, and treatment by day interaction were assessed using PROC MIXED (SAS Institute Inc.) and cow as the random effect. To compare with baseline, the overall effects period and treatment (and their interaction) were also analyzed using PROC MIXED. All data are reported as least squares means and considered significant if $P \leq 0.05$ and a tendency if $0.05<P \leq 0.10$.

\section{RESULTS}

Detailed production and immunological data are presented in the companion paper (Dickson et al., 2019); in brief, feed intake milk yield initially decreased (d 1 of infusion) and progressively increased with time. Milk yield did not differ by treatment and, by experimental design, the extent and pattern of DMI did not differ. Circulating glucose did not differ between treatments during P2 $(P=0.42$; Figure $2 \mathrm{~A})$ and was not different compared with P1. Relative to baseline values, P2 circulating insulin tended to be decreased in CON-PF cows $(47 \% ; P=0.08)$, whereas in LPS-AL cows it did not change $(P=0.42)$. Overall, this resulted in a $140 \%$ increase in basal insulin from LPS-AL versus CON-PF cows $(P=0.01$; Figure $2 \mathrm{~B})$. During $\mathrm{P} 2$, the insulin-toglucose ratio of LPS-AL cows increased $(136 \%)$ relative to CON-PF cows $(P<0.01$; data not shown). Circulating NEFA increased from d 1 to 3 and subsequently decreased from d 3 to 7 in both treatments $(P<0.01$; 
Figure 2C). Relative to P1, CON-PF cows had a $29 \%$ decrease in plasma BHB $(P=0.04)$, whereas BHB in LPS-AL did not change $(P=0.40)$; thus, LPS-AL cows had overall increased BHB relative to CON-PF cows (41\%; $P=0.01$; Figure 3A). Circulating L-lactate of CON-PF cows remained unchanged throughout P2, whereas in LPS-AL cows it tended to initially increase and then returned to baseline $(P=0.06$; Figure $3 \mathrm{~B})$. Circulating BUN gradually decreased in CON-PF cows but increased in LPS-AL cows from d 1 to $5(P=0.03)$, resulting in an overall $25 \%$ increase in LPS-AL versus CON-PF cows $(P=0.02$; Figure $3 \mathrm{C})$.

Chronic LPS exposure had no detectable effect on protein abundance of intracellular insulin-signaling molecules (INSR- $\beta$, IRS-1, phosphor-IRS-1, Akt, phosphor-Akt) in adipose, muscle, or liver (Table 2; $P$ $\geq 0.17$ ). Further, liver transcript abundance of genes related to gluconeogenesis ( $G 6 P C$ and $P C K 1)$ and lipid oxidation and transport $(A C O X 1, A P O A 5$, and $A P O B 100$ ) were unaffected by LPS exposure (Table 3; $P \geq 0.21)$. Liver triglyceride content $(2 \%)$ was similar between treatments (data not shown; $P=0.47$ ).

In response to the GTT, glucose AUC was increased (33\%; 3,367 vs. $2,523 \mathrm{mg} / \mathrm{dL} \cdot \mathrm{min})$ in LPS-AL cows relative to CON-PF cows $(P=0.02$; Figure $4 \mathrm{~A})$. Similarly, LPS-AL cows had a $56 \%$ increase in insulin AUC relative to $\mathrm{CON}-\mathrm{PF}$ cows $(414 \mathrm{vs} .265 \mu \mathrm{g} / \mathrm{L} \cdot \mathrm{min} ; P=$ 0.03; Figure 4B). The overall (i.e., average of all values postbolus) insulin-to-glucose ratio following the GTT of LPS-AL cows increased (54\%) relative to CON-PF cows $(P<0.01$; data not shown). In response to the EC, neither glucose nor NEFA AUC differed between treatments $(P \geq 0.53$; Figure $5 \mathrm{~A}$ and $5 \mathrm{~B})$.

\section{DISCUSSION}

Infection and inflammation impede efficient animal agriculture productivity, and both begin with PAMP (e.g., bacteria, viruses, yeast, parasites) recognition by various cell types (i.e., leukocytes, myocytes, hepatocytes, and so on) eliciting transcription and production of inflammatory cytokines. Immunoactivation is commonly modeled through bolus LPS administration, which prompts a well-characterized and robust immune response (van Miert and Frens, 1968; Lohuis et al., 1988). However, this model likely inadequately mimics natural endotoxin exposure. Alternatively, chronically infusing a specific cytokine is an approach to evaluate the metabolic consequences of inflammation (Bradford et al., 2009; Yuan et al., 2013; Martel et al., 2014), but this strategy lacks the dynamic and temporal profile of multiple proinflammatory (and anti-inflammatory) cytokines that accompany natural infection. Thus, the current strategy of continuous LPS infusion over sev-
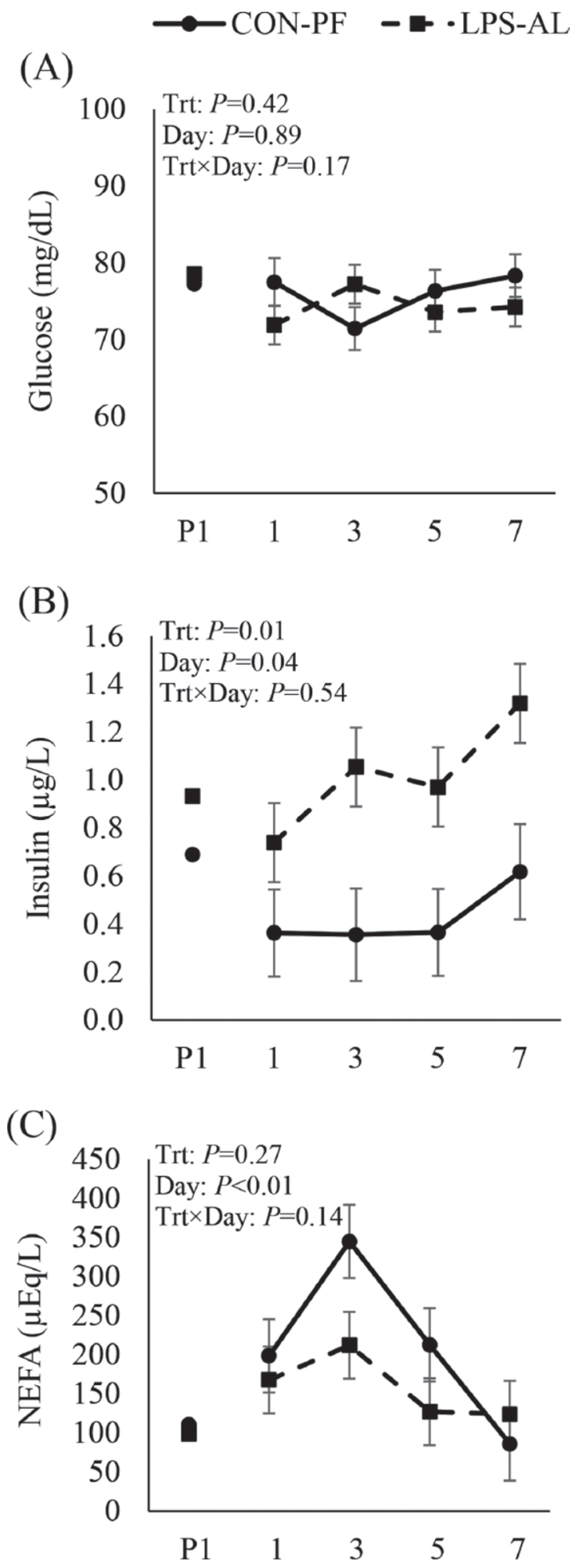

Day relative to infusion start

Figure 2. Circulating daily levels of (A) glucose, (B) insulin, and (C) nonesterified fatty acids (NEFA) in cows administered a continuous and increasing dose of LPS (LPS-AL) or sterile saline and pairfed $(\mathrm{CON}-\mathrm{PF})$ with LPS-infused cows. P1 $=$ period 1 . Results are expressed as LSM \pm SEM. 


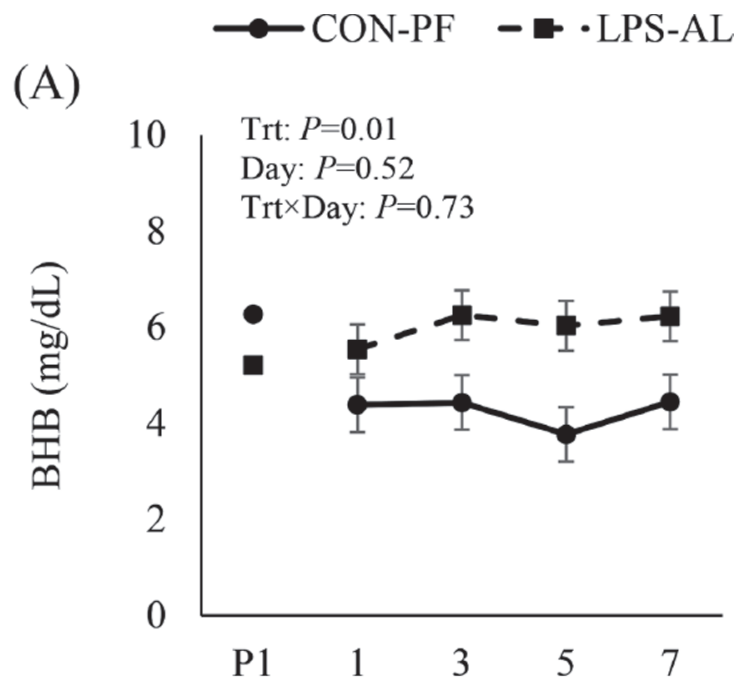

(B)

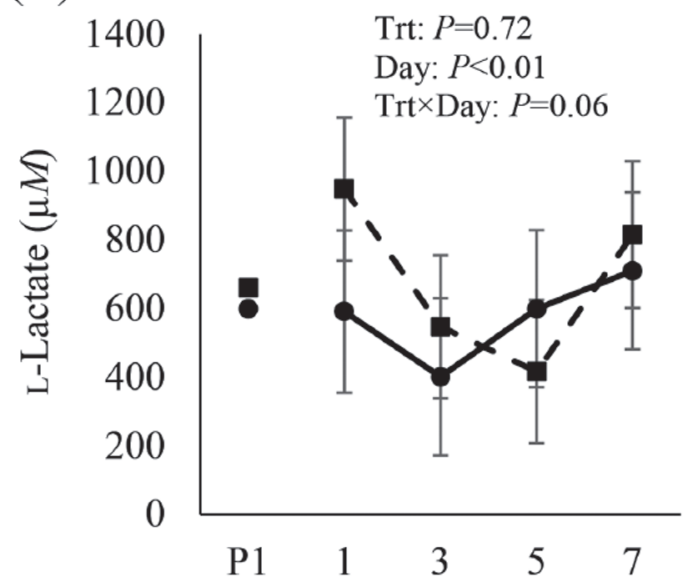

(C)

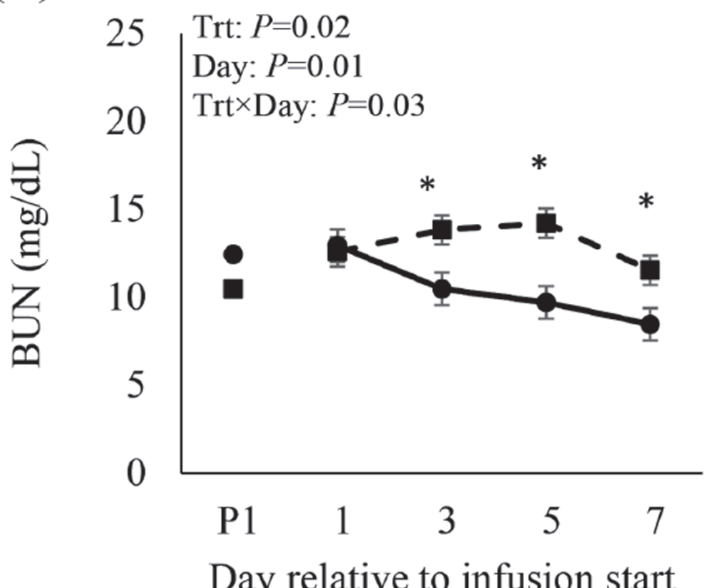

Figure 3. Circulating daily levels of (A) BHB, (B) L-lactate, and (C) BUN in cows administered a continuous and increasing dose of LPS (LPS-AL) or sterile saline and pair-fed (CON-PF) with LPSinfused cows. ${ }^{*}$ Indicates treatment differences at the indicated time point $(P<0.05)$. P1 $=$ period 1 . Results are expressed as LSM \pm SEM. eral days is an attempt to more accurately model the inflammatory milieu that accompanies real infections and the dynamic release of endotoxin upon bacterial growth and proliferation (Crutchley et al., 1967; Goris et al., 1988).

Lipopolysaccharide infusion includes PAMP recognition and nuclear factor kappa B pathway initiation, which elicits production of several cytokines, including IL-1 $\beta$ and IL- 6 in addition to tumor necrosis factor $\alpha$ (TNF $\boldsymbol{\alpha}$; Murphy, 2012), and each cytokine distinctly influences the pattern and production of acute phase proteins (Gabay and Kushner, 1999). Inherently, microorganisms replicate quickly, and in vivo endotoxin exposure can (if not controlled and remedied by the immune system) rapidly intensify (Burvenich et al., 2007). We chose to increase the daily LPS dose exponentially (Figure 1) in an attempt to more accurately mimic endotoxin exposure during bacterial overgrowth while minimizing the likelihood of a lethal outcome. Initially, a relatively low dose was used $(0.4 \mu \mathrm{g} / \mathrm{kg}$ of BW over $24 \mathrm{~h}$ ) and it sequentially increased to an extremely high quantity if given as a bolus $(3.56 \mu \mathrm{g} / \mathrm{kg}$ of BW over 24 $\mathrm{h}$ on $\mathrm{d} 7$ and 8). In fact, a bolus dose of just $2.0 \mu \mathrm{g} /$ $\mathrm{kg}$ of BW can be fatal in LPS-naive lactating cows (Waldron et al., 2003). That there were little to no effects on most production variables by the end of the current experiment illustrates the profound capabilities of cows to develop tolerance to constant LPS exposure (Dickson et al., 2019).

An unexplainable increase in circulating insulin (an acute and intensely anabolic hormone) is a wellconserved metabolic response to immunoactivation (Vernay et al., 2012; Baumgard et al., 2016). In agreement with LPS bolus models (Waldron et al., 2003; Toribio et al., 2005; Waggoner et al., 2009b; Yates et al., 2011; Kvidera et al., 2016a,b, 2017), basal hyperinsulinemia was observed throughout P2 and was one of the most marked metabolic treatment differences detected in the current study. Incidentally, this agrees with long-term (10 d) continuous TNFo infusion, which increased circulating insulin in rodents (Raina et al., 1995). Hyperinsulinemia may reflect an approach to facilitate leukocyte glucose uptake and function during immunoactivation, as immune cells are insulin sensitive and require copious amounts of glucose (Helderman, 1984; Calder et al., 2007; Maratou et al., 2007).

In contrast to leukocytes, peripheral tissues such as adipose tissue and skeletal muscle, become insulin resistant during immunoactivation, presumably in a synchronized effort to spare glucose for activated leukocytes (Lang et al., 1990). Interestingly, both basal and stimulated metabolic parameters evaluated herein were indicative of systemic insulin resistance. For instance, changes in circulating basal insulin were not reflected 
Table 2. Effects of continuous LPS infusion on relative protein abundance ${ }^{1}$

\begin{tabular}{|c|c|c|c|c|}
\hline \multirow[b]{2}{*}{ Parameter $^{2}$} & \multicolumn{2}{|c|}{ Treatment $^{3}$} & \multirow[b]{2}{*}{ SEM } & \multirow{2}{*}{$\frac{P \text {-value }}{\text { Treatment }}$} \\
\hline & CON-PF & LPS-AL & & \\
\hline \multicolumn{5}{|l|}{ Liver } \\
\hline IRS-1 & 36,452 & 29,745 & 3,298 & 0.19 \\
\hline p-IRS-1 & 53,126 & 45,469 & 3,571 & 0.17 \\
\hline p-IRS-1:IRS-1 & 1.47 & 1.66 & 0.21 & 0.54 \\
\hline Akt & 24,115 & 20,918 & 4,207 & 0.61 \\
\hline p-Akt & 39,379 & 34,478 & 3,426 & 0.34 \\
\hline p-Akt:Akt & 1.87 & 1.94 & 0.424 & 0.91 \\
\hline INSR- $\beta$ & 68.37 & 59.87 & 8.99 & 0.52 \\
\hline \multicolumn{5}{|l|}{ Adipose tissue } \\
\hline IRS-1 & 16,351 & 18,371 & 4,614 & 0.72 \\
\hline p-IRS-1 & 49,364 & 53,519 & 5,824 & 0.61 \\
\hline p-IRS-1:IRS-1 & 3.81 & 3.47 & 0.94 & 0.81 \\
\hline Akt & 131.50 & 88.79 & 21.16 & 0.19 \\
\hline p-Akt & 20.82 & 14.94 & 6.38 & 0.53 \\
\hline p-Akt:Akt & 0.15 & 0.24 & 0.07 & 0.38 \\
\hline INSR- $\beta$ & 132.54 & 127.98 & 12.90 & 0.81 \\
\hline \multicolumn{5}{|l|}{ Muscle } \\
\hline IRS-1 & 41,274 & 38,692 & 4,985 & 0.72 \\
\hline p-IRS-1 & 41,343 & 41,660 & 8,552 & 0.98 \\
\hline p-IRS-1:IRS-1 & 1.09 & 1.07 & 0.22 & 0.94 \\
\hline Akt & 51,432 & 46,632 & 5,366 & 0.54 \\
\hline p-Akt & 16,753 & 14,236 & 3,274 & 0.60 \\
\hline p-Akt:Akt & 0.31 & 0.32 & 0.06 & 0.97 \\
\hline INSR- $\beta$ & 120.65 & 106.94 & 16.11 & 0.57 \\
\hline
\end{tabular}

${ }^{1}$ Data reported as $\mathrm{LSM} \pm \mathrm{SEM}$.

${ }^{2}$ IRS-1 = insulin receptor substrate-1; Akt = protein kinase B; INSR- $\beta=$ insulin receptor- $\beta$; $\mathrm{p}=$ phosphorylated.

${ }^{3} \mathrm{CON}-\mathrm{PF}=$ saline infused, pair-fed; LPS-AL $=$ LPS infused, ad libitum feed intake.

by decreased circulating glucose. In response to the GTT, rates of glucose disposal were decreased by LPS. Furthermore, in both basal and stimulated metabolic states, the insulin-to-glucose ratio was increased in LPS-AL cows relative to PF controls.

Coupled with aforementioned whole-body glucosesparing mechanisms, activated leukocytes switch their metabolism from oxidative phosphorylation to aerobic glycolysis in a phenomenon termed the "Warburg effect" (Palsson-McDermott and O'Neill, 2013). This substantially increases glucose consumption to sup-

Table 3. Effects of continuous LPS infusion on relative liver mRNA abundance $^{1}$

\begin{tabular}{lccc}
\hline & \multicolumn{2}{c}{ Treatment $^{2}$} & \\
\cline { 2 - 3 } Gene & CON-PF & LPS-AL & $P$-value \\
\hline ACOX1 & $1 \pm 0.57$ & $0.84 \pm 0.35$ & 0.88 \\
APOA5 & $1 \pm 1.05$ & $0.71 \pm 0.30$ & 0.85 \\
APOB100 & $1 \pm 0.22$ & $2.34 \pm 0.89$ & 0.21 \\
G6PC & $1 \pm 0.62$ & $0.63 \pm 0.20$ & 0.96 \\
PCK1 & $1 \pm 0.76$ & $0.38 \pm 0.09$ & 0.96 \\
\hline
\end{tabular}

${ }^{1}$ Data reported as LSM \pm SEM.

${ }^{2} \mathrm{CON}-\mathrm{PF}=$ saline infused, pair-fed; LPS-AL $=$ LPS infused, ad libitum feed intake. port energetic and substrate demand and increases generation and export of lactate (Michaeli et al., 2012; Kvidera et al., 2017). However, circulating lactate did not differ between treatments in the current chronic LPS administration study. Exact reasons for not observing hyperlactatemia are ill-defined, but evidently the removal of circulating lactate kept pace with the presumed increase in lactate entry into the pool. A probable explanation is that systemic tissues (which become refractory to insulin during infection) ostensibly increase their reliance on lactate as a fuel. Additionally, hepatic lactate uptake probably increased to provide a precursor for endotoxemia-induced enhanced rates of gluconeogenesis, as has been described in laboratory animal models (Filkins, 1978) and lactating dairy cows (Waldron et al., 2003).

Insulin-resistant peripheral tissues undergo further metabolic adjustments to support the high energetic demand of leukocytes. For example, infection increases skeletal muscle proteolysis to provide AA as substrates for gluconeogenesis (Wannemacher et al., 1980) and the biosynthesis of leukocytes and acute phase proteins (Iseri and Klasing, 2013). The profile of the immune system's AA requirement differs from skeletal muscle, thus excess muscle is catabolized to meet the immune 
system requirement (Reeds et al., 1994). Not surprisingly, circulating BUN is consistently increased in pig models of endotoxemia (Myers et al., 1997; Bruins et al., 2003). Results from ruminants generally agree (Burdick Sanchez et al., 2014), but are more variable (Waggoner et al., 2009a,b; Zarrin et al., 2014), probably due to the contribution of rumen derived ammonia. Further, changes in BUN may be masked by hypophagia-induced alterations in substrate delivery (i.e., AA) and changes to the rumen microbiome (Jing et al., 2014). Therefore, utilizing a pair-feeding model to account for decreased feed intake in ruminant models is important. Data from the current study corroborate monogastric reports, as circulating BUN decreased gradually in CON-PF but increased in LPS-AL cows (Figure 3C). Thus, endotoxemia-induced increased muscle catabolism likely occurs in lactating dairy cows as well. It would be of interest to measure more appropriate markers (e.g., 3-methylhistidine, urine creatinine, and so on) to confirm whether muscle catabolism occurs during immunoactivation in ruminants.

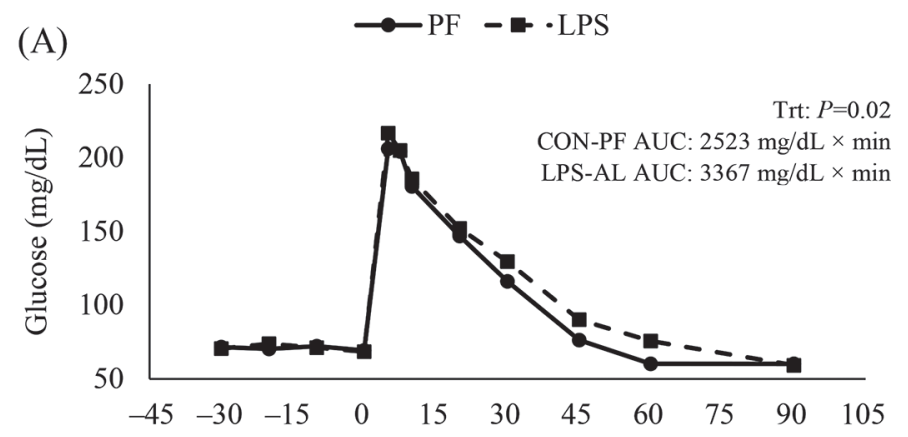

(B)

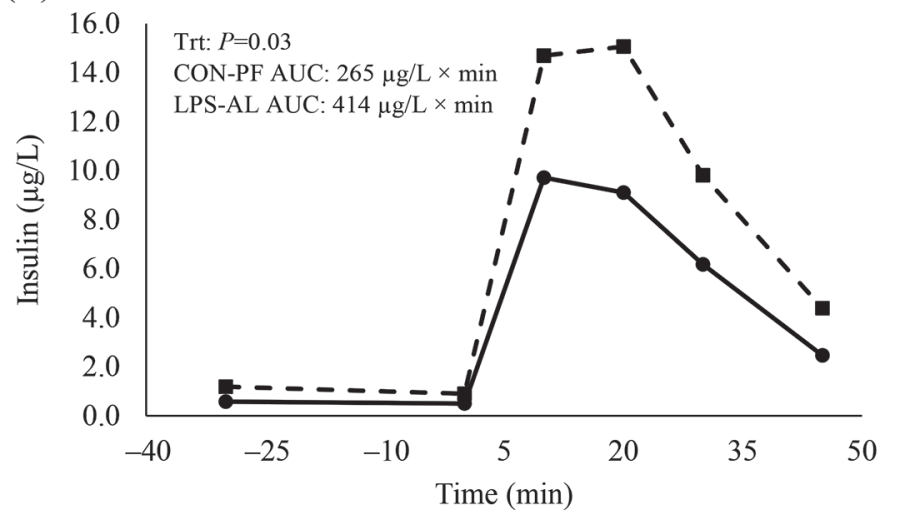

Figure 4. Circulating (A) glucose and (B) insulin response to an intravenous glucose tolerance test during d 8 of continuous and increasing LPS infusion (LPS-AL) or sterile saline and pair-fed (CONPF) with LPS-infused cows. The SEM was $198 \mathrm{mg} / \mathrm{dL} \times \min$ and 37 $\mu \mathrm{g} / \mathrm{L} \times \min$ for glucose and insulin, respectively. Results are expressed as LSM.
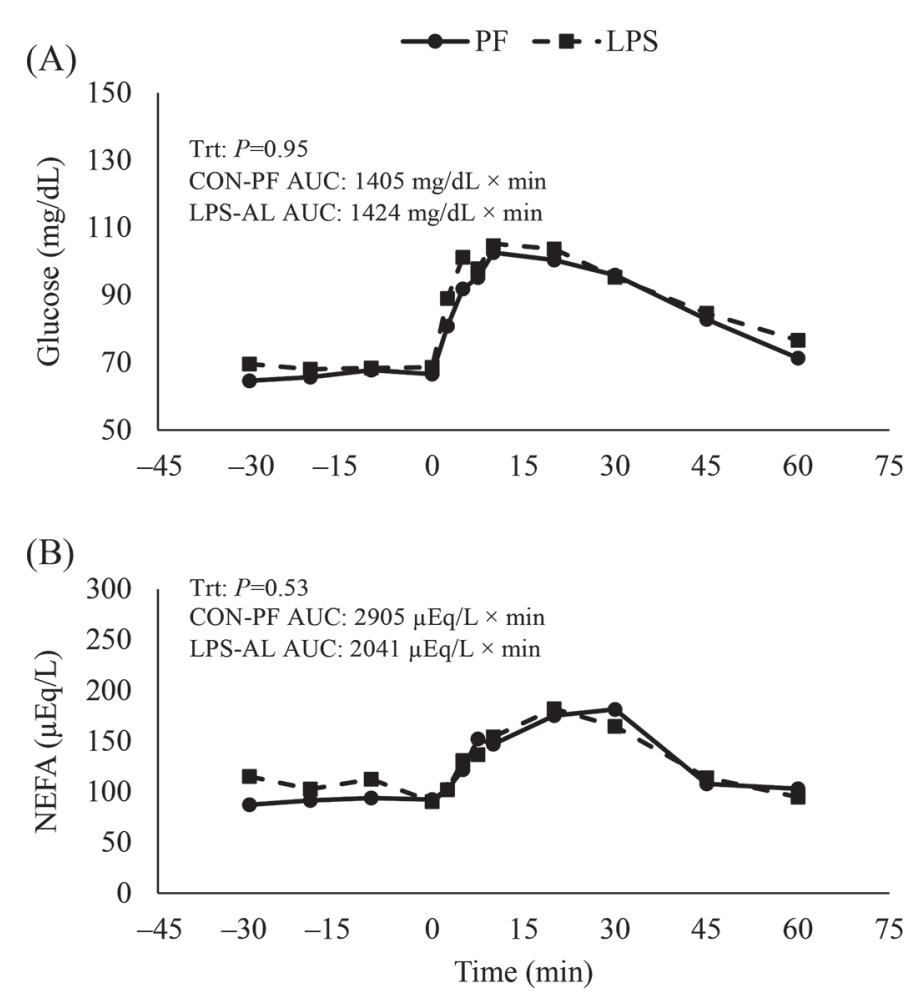

Figure 5. Circulating (A) glucose and (B) nonesterified fatty acids (NEFA) response to an intravenous epinephrine challenge during d 8 of continuous and increasing LPS infusion (LPS-AL) or sterile saline and pair-fed (CON-PF) with LPS-infused cows. The SEM was $200 \mathrm{mg} /$ $\mathrm{dL} \times \min$ and $916 \mu \mathrm{Eq} / \mathrm{L} \times \min$ for glucose and NEFA, respectively. Results are expressed as LSM.

Although not always consistent (Waldron et al., 2006; Zarrin et al., 2014), adipose tissue lipolysis is increased in response to LPS (Waldron et al., 2003) and TNFQ administration (Kushibiki et al., 2002). Previous studies conducted by our group have demonstrated increased basal NEFA relative to baseline in LPS bolus-administered animals, but this response is blunted relative to the NEFA pattern of PF controls (Kvidera et al., 2016a, 2017; Horst et al., 2018). Herein, patterns of unstimulated circulating NEFA were similar between LPS-infused and PF animals (Figure 2C). This is surprising, as basal insulin was increased $140 \%$ in LPS-administered cows and insulin is a potent antilipolytic hormone (Vernon, 1992). Reasons why basal NEFA levels are inconsistent among studies are not clear, but may stem from differences in dose, timing, and route of LPS administration.

Previous reports have demonstrated both blunted lipolysis and a diminished glucose response to adrenergic stimulation during sepsis (Forse et al., 1987; Hargrove et al., 1989). Hargrove et al. (1990) suggested this was primarily due to increased circulating endotoxemiainduced hyperinsulinemia. However, the blunted 
response to adrenergic stimulation could also be due to desensitization of adrenergic receptors, as epinephrine is increased during both heat stress (Alvarez and Johnson, 1973) and an endotoxin challenge in humans, cattle, and sheep (Richardson et al., 1989; Williams et al., 2009; Burdick et al., 2011). Chronically increased circulating epinephrine can downregulate and desensitize adrenergic receptors (Briggs et al., 1983; Snavely et al., 1985), potentially inducing resistance to adrenergic signaling. Surprisingly, despite the LPS-induced hyperinsulinemia, no changes in adipose lipolysis or hepatic glucose output (glycogenolysis) in response to the EC were detected in the current study. It would be of interest to evaluate both the temporal pattern and immunoactivation model (acute vs. chronic) effects on liver and adipose tissue responsiveness to catabolic signals during endotoxemia.

Altered lipid metabolism during infection is not exclusive to adipocytes, but occurs within hepatocytes as well. Inflammation increases liver lipid accumulation both directly through changes in lipid oxidation and transport enzymes and indirectly through increased circulating NEFA (Endo et al., 2007; Bradford et al., 2009). However, no differences in hepatic TAG content were observed in the current study. Reasons for why we did not observe hepatic steatosis are not clear, but lack of a simultaneous and biologically meaningful increase in NEFA (similar to the transition cow) may help explain this result. It would be of practical importance to evaluate how transition cow inflammation (Bradford et al., 2015; Abuajamieh et al., 2016) contributes to fatty liver metabolic maladaptation to lactation.

Circulating BHB was decreased in PF cows, but was maintained at baseline levels in LPS-infused cows. Interestingly, the discordant BHB patterns occurred despite cows from both treatments having similar concentrations of circulating NEFA. The majority of circulating BHB during positive energy balance originates from the rumen epithelium as opposed to the liver (Pennington, 1952). The maintenance of ketone levels in LPS-infused cows relative to PF controls could be caused by 1 of 3 factors: (1) decreased ketone utilization by peripheral tissue, (2) increased absorption efficiency by the rumen epithelium, or (3) increased hepatic ketone production. A decrease in ketone utilization is not likely, as ketones may provide an energy source for nonimmune tissues during LPS-induced insulin resistance, as previously hypothesized (Zarrin et al., 2014). An increased rate of BHB infusion was required to maintain hyperketonemia in lactating cows challenged with LPS (Zarrin et al., 2014), indicating increased circulating BHB clearance. Administering LPS also decreases rumen motility and increases rumen butyrate concentrations, changes indicative of poor rumen ketone absorptive capacity (Jing et al., 2014). Lastly, Waldron et al. (2003) observed no LPS effects on ketone synthesis in incubated liver slices obtained from lactating cows, indicating ketogenesis remains functional. However, other animal models demonstrated reduced hepatic ketogenesis during inflammation, attributed to either insulin's lipogenic role in both hepatocytes and adipocytes (a scenario reducing substrate delivery for ketogenesis; Beisel and Wannemacher, 1980; Neufeld et al., 1980) or direct antiketogenic effects of inflammatory cytokines (Memon et al., 1992). We and others have shown reduced circulating BHB following bolus endotoxin administration (Graugnard et al., 2013; Zarrin et al., 2014; Kvidera et al., 2016a, 2017) and LPS infused over $100 \mathrm{~min}$ (Waldron et al., 2003), which contradicts the results of the current study. One factor potentially responsible for these differences may be the LPS dose. Larger LPS doses cause more robust metabolic alterations (Lohuis et al., 1988; Waldron et al., 2003); therefore, most bolus studies use an extensive LPS dose to accurately observe and measure changes. Herein, the dose initially used was quite low and increased exponentially; therefore, metabolic shifts were certainly not as dramatic and endotoxin tolerance obviously developed. Thus, it is very likely ketone metabolism differs in this model compared with bolus administration. Very little literature exists (in any species) on the effect of chronic inflammation on ketone metabolism, but further evaluation of this area is obviously relevant to transition dairy cows.

As a supplement to our basal and metabolic parameters presented herein, we assessed metabolic changes at the molecular level. As previously mentioned, inflammation-induced changes in lipid metabolism occur within both adipocytes and hepatocytes. At the molecular level, Bradford et al. (2009) observed increased fatty acid translocase (CD36; a mediator of free fatty acid uptake), and 1-acylglycerol-3-phosphate O-acyltransferase 1 (regulator of fatty acyl-CoA esterification to the glycerol backbone) following $7 \mathrm{~d}$ of $\mathrm{TNF} \alpha$ infusion. However, in agreement with no change in circulating NEFA (Figure 2C) or hepatic triglyceride content (data not shown), transcript abundance of $A P O B 100$ and APOA5 (key enzymes involved in the synthesis and export of very low density lipoprotein) were similar between treatments. Additionally, mRNA abundance of $A C O X 1$ (an enzyme involved in lipid oxidation) did not differ between treatments. Reasons for not observing changes in hepatic lipid metabolism remain unclear, but are likely explained by the development of immunotolerance and the lack of a meaningful increase in circulating NEFA.

Similar to unaltered hepatic lipid metabolism markers, no treatment differences in hepatic mRNA abundance of $P C K 1$ and $G 6 P C$ (2 rate-limiting glu- 
coneogenic enzymes) were observed. Reasons for the unaltered response are not clear, but may be explained by differences in acute versus chronic models, the stage of infection, or the evaluation of only 1 time point (after $7 \mathrm{~d}$ ). Additionally, due to the complicated nature of protein synthesis and the potential for post-translational modifications, a gene's mRNA abundance is not necessarily directly correlated with protein abundance. Further investigation of the temporal pattern in hepatic glucose output (via more direct measures) during chronic LPS exposure is needed.

Based upon both basal and stimulated metabolic parameters, chronic LPS exposure clearly caused whole-body insulin resistance. At the molecular level, peripheral insulin resistance is partly mediated by increased circulating cytokines, which induce IRS-1 serine phosphorylation. This phosphorylation inhibits tyrosine kinase activity of IRS-1 and, consequently, blunts insulin signaling (as reviewed by Taha and Klip, 1999). Although less established in the ruminant literature, several human and rodent studies have observed altered expression of central proteins within the insulinsignaling pathway, changes indicative of insulin resistance following both LPS (Fan et al., 1996; Liang et al., 2013; Wakayama et al., 2014) and TNFo (Hotamisligil et al., 1994; Plomgaard et al., 2005) administration. In contrast to the human and rodent literature, as well as our basal and stimulated metabolic parameters, we observed no effect of chronic LPS exposure on protein abundance of INSR- $\beta$, IRS-1, phosphor-IRS- 1 , Akt, or phosphor-Akt or their ratios within the liver, skeletal muscle, or adipose tissue. Reasons for the discrepancies in the interpretation of systemic and molecular insulin action are unclear; the molecular data may be limited by insufficient cows per treatment and the evaluation of 1 time point, whereas the metabolic data are temporal, repeated, and the basal and stimulated responses corroborate each other.

Perhaps the biggest pitfall of our molecular results is the inability to distinguish cell types within a tissue. Due to the immune system's ubiquitous nature and fluctuating distribution throughout tissues, it can be difficult to assess changes in tissue insulin sensitivity during immunoactivation. Mészáros et al. (1991) demonstrated that tissues containing a large immune compartment (i.e., liver or spleen) increase glucose consumption following endotoxin exposure, indicative of increased insulin sensitivity of leukocytes rather than extraimmune cells. Increased immune cell infiltration into adipose tissue and muscle depots has been observed previously in both small animal (Peterson et al., 2006) and ruminant models (Akter et al., 2012; Contreras et al., 2016). Interestingly, this agrees with Lumeng et al.
(2007), who observed a dose-dependent increase in basal glucose uptake of adipocytes that were co-cultured with increasing amounts of macrophages. Therefore, it is possible that leukocyte infiltration influenced our measurements of insulin signaling proteins. However, differences in acute versus chronic models and a hyporesponsive state cannot be excluded.

Surprisingly, despite obviously developing tolerance (from a production standpoint; see Dickson et al., 2019), changes in whole-body nutrient partitioning were reflective of systemic infection. During natural infection, bacteria replicate on a logistic rather than an exponential curve and the microbial population consists of multiple species and strains differing in virulence (Contois, 1959; Crutchley et al., 1967). To reduce the risk of mortality, we chose to begin with a more conservative approach (i.e., an exponential curve). It would be of scientific and practical interest to develop and implement a model more representative of natural infection.

\section{CONCLUSIONS}

A variety of studies have characterized LPS-induced metabolic effects using bolus or repeated administration models. We attempted to more accurately represent chronic in vivo infection by infusing LPS continuously with exponentially increasing doses for $8 \mathrm{~d}$. The most striking effect of uninterrupted low-dose LPS infusion was chronically elevated circulating insulin. The lack of changes in basal circulating glucose coupled with the decrease in glucose disposal following the GTT indicates that chronic LPS infusion caused whole-body insulin resistance. Increased circulating BUN and BHB in LPS-infused cows also suggests protein and lipid metabolism are altered during continuous LPS exposure. Furthermore, because both treatments had a similar catabolic response to epinephrine despite increased insulin in LPS-infused animals, it appears chronic LPS infusion may diminish insulin's inhibitory role on both hepatic glucose output and adipose tissue lipolysis. Despite the aforementioned metabolic consequences, feed intake and milk yield were essentially unaffected by chronic endotoxin infusion, a scenario that illustrates the remarkable ability for cows to generate LPS tolerance or that our infusion protocol was too passive and inadequately replicated natural infection.

\section{ACKNOWLEDGMENTS}

Results described herein were supported in part by the Agricultural and Food Research Initiative Competitive Grant no. 2017- 05931 from the USDA National 
Institute of Food and Agriculture (Washington, DC) and the Norman Jacobson Endowed Professorship at Iowa State University.

\section{REFERENCES}

Abuajamieh, M., S. K. Kvidera, E. A. Horst, E. J. Mayorga, J. T. Seibert, J. S. Johnson, J. W. Ross, M. A. Al-Qaisi, P. J. Gorden, J. DeFrain, R.P. Rhoads, and L. H. Baumgard. 2016. The effects of zinc amino acid complex on biomarkers of gut integrity and metabolism in heat-stressed steers. J. Dairy Sci. 99(E-Suppl. 1):1175.

Akter, S. H., S. Häussler, D. Germeroth, D. von Soosten, S. Dänicke, K. H. Südekum, and H. Sauerwein. 2012. Immunohistochemical characterization of phagocytic immune cell infiltration into different adipose tissue depots of dairy cows during early lactation. J. Dairy Sci. 95:3032-3044.

Alvarez, M. B., and H. D. Johnson. 1973. Environmental heat exposure on cattle plasma catecholamine and glucocorticoids. J. Dairy Sci. 56:189-194.

Baumgard, L. H., B. A. Corl, D. A. Dwyer, and D. E. Bauman. 2002. Effects of conjugated linoleic acids (CLA) on tissue response to homeostatic signals and plasma variables associated with lipid metabolism in lactating dairy cows. J. Anim. Sci. 80:1285-1293.

Baumgard, L. H., G. J. Hausman, and M. V. Sanz Fernandez. 2016. Insulin: Pancreatic secretion and adipocyte regulation. Domest. Anim. Endocrinol. 54:76-84.

Beeson, P. B. 1947. Tolerance to bacterial pyrogens. I. Factors influencing its development. J. Exp. Med. 86:29-38.

Beisel, W. R., and R. W. Wannemacher. 1980. Gluconeogenesis, ureagenesis, and ketogenesis during sepsis. JPEN J. Parenter. Enteral. Nutr. 4:277-285.

Bradford, B. J., L. K. Mamedova, J. E. Minton, J. S. Drouillard, and B. J. Johnson. 2009. Daily injection of tumor necrosis factor-alpha increases hepatic triglycerides and alters transcript abundance of metabolic genes in lactating dairy cattle. J. Nutr. 139:1451-1456.

Bradford, B. J., K. Yuan, J. K. Farney, L. K. Mamedova, and A. J. Carpenter. 2015. Invited review: Inflammation during the transition to lactation: New adventures with an old flame. J. Dairy Sci. 98:6631-6650.

Briggs, M. M., J. M. Stadel, R. Iyengar, and R. J. Lefkowitz. 1983. Functional modification of the guanine nucleotide regulatory protein after desensitization of turkey erythrocytes by catecholamines. Arch. Biochem. Biophys. 224:142-151.

Bruins, M. J., N. E. Deutz, and P. B. Soeters. 2003. Aspects of organ protein, amino acid and glucose metabolism in a porcine model of hypermetabolic sepsis. Clin. Sci. (Lond.) 104:127-141.

Burdick, N. C., J. A. Carroll, L. E. Hulbert, J. W. Dailey, M. A. Ballou, R. D. Randel, S. T. Willard, R. C. Vann, and T. H. Welsh. 2011. Temperament influences endotoxin-induced changes in rectal temperature, sickness behavior, and plasma epinephrine concentrations in bulls. Innate Immun. 17:355-364.

Burdick Sanchez, N. C., J. A. Carroll, R. D. Randel, R. C. Vann, and T. H. Welsh. 2014. Associations between endotoxin-induced metabolic changes and temperament in Brahman bulls. J. Anim. Physiol. Anim. Nutr. (Berl.) 98:178-190.

Burvenich, C., D. D. Bannerman, J. D. Lippolis, L. Peelman, B. J. Nonnecke, M. E. Kehrli Jr, and M. J. Paape. 2007. Cumulative physiological events influence the inflammatory response of the bovine udder to Escherichia coli infections during the transition period. J. Dairy Sci. 90(E. Suppl.):E39-E54.

Calder, P. C., G. Dimitriadis, and P. Newsholme. 2007. Glucose metabolism in lymphoid and inflammatory cells and tissues. Curr. Opin. Clin. Nutr. Metab. Care 10:531-540.

Contois, D. E. 1959. Kinetics of bacterial growth: Relationship between population density and specific growth rate of continuous cultures. J. Gen. Microbiol. 21:40-50.

Contreras, G. A., K. Thelen, S. E. Schmidt, C. Strieder-Barboza, C. L. Preseault, W. Raphael, M. Kiupel, J. Caron, and A. L. Lock.
2016. Adipose tissue remodeling in late-lactation dairy cows during feed-restriction-induced negative energy balance. J. Dairy Sci. 99:10009-10021.

Crutchley, M. J., D. G. Marsh, and J. Cameron. 1967. Free endotoxin. Nature 214:1052.

Dickson, M., S. Stoakes, E. Horst, C. Wiley, E. Mayorga, J. Ydstie, G. Perry, L. Baumgard, and A. Keating. 2019. Impact of chronic and increasing lipopolysaccharide exposure on production and reproductive parameters in lactating Holstein dairy cows. J. Dairy Sci. 102:3569-3583. https://doi.org/10.3168/jds.2018-15631.

Endo, M., T. Masaki, M. Seike, and H. Yoshimatsu. 2007. TNF-alpha induces hepatic steatosis in mice by enhancing gene expression of sterol regulatory element binding protein-1c (SREBP-1c). Exp. Biol. Med. (Maywood) 232:614-621.

Fan, J., Y. H. Li, M. M. Wojnar, and C. H. Lang. 1996. Endotoxininduced alterations in insulin-stimulated phosphorylation of insulin receptor, IRS-1, and MAP kinase in skeletal muscle. Shock 6:164-170.

Filkins, J. P. 1978. Phases of glucose dyshomeostasis in endotoxicosis. Circ. Shock 5:347-355.

Forse, R. A., R. Leibel, J. Askanazi, J. Hirsch, and J. M. Kinney. 1987. Adrenergic control of adipocyte lipolysis in trauma and sepsis. Ann. Surg. 206:744-751.

Gabay, C., and I. Kushner. 1999. Acute-phase proteins and other systemic responses to inflammation. N. Engl. J. Med. 340:448-454.

Goris, H., F. de Boer, and D. van der Waaij. 1988. Kinetics of endotoxin release by gram-negative bacteria in the intestinal tract of mice during oral administration of bacitracin and during in vitro growth. Scand. J. Infect. Dis. 20:213-219.

Graugnard, D. E., K. M. Moyes, E. Trevisi, M. J. Khan, D. Keisler, J. K. Drackley, G. Bertoni, and J. J. Loor. 2013. Liver lipid content and inflammometabolic indices in peripartal dairy cows are altered in response to prepartal energy intake and postpartal intramammary inflammatory challenge. J. Dairy Sci. 96:918-935.

Gröhn, Y. T., D. J. Wilson, R. N. González, J. A. Hertl, H. Schulte, G. Bennettm, and Y. H. Schukken. 2004. Effect of pathogen-specific clinical mastitis on milk yield in dairy cows. J. Dairy Sci. 87:3358-3374.

Hargrove, D. M., C. H. Lang, G. J. Bagby, and J. J. Spitzer. 1989. Epinephrine-induced increase in glucose turnover is diminished during sepsis. Metabolism 38:1070-1076.

Hargrove, D. M., N. Skrepnik, C. H. Lang, G. J. Bagby, and J. J. Spitzer. 1990. Role of insulin in the blunted glucose metabolic response of septic rats to epinephrine. Metabolism 39:1180-1185.

Helderman, J. H. 1984. Acute regulation of human lymphocyte insulin receptors. Analysis by the glucose clamp. J. Clin. Invest. 74:1428-1435.

Horst, E. A., S. K. Kvidera, E. J. Mayorga, C. S. Shouse, M. Al-Qaisi, M. J. Dickson, J. Ydstie, H. A. Ramirez Ramirez, A. F. Keating, D. J. Dickson, K. E. Griswold, and L. H. Baumgard. 2018. Effect of chromium on bioenergetics and leukocyte dynamics following immunoactivation in lactating Holstein cows. J. Dairy Sci. 101:5515-5530.

Hotamisligil, G. S., D. L. Murray, L. N. Choy, and B. M. Spiegelman. 1994. Tumor necrosis factor $\alpha$ inhibits signaling from the insulin receptor. Proc. Natl. Acad. Sci. U.S.A. 91:4854-4858.

Huntley, N. F., C. M. Nyachoti, and J. F. Patience. 2017. Immune system stimulation increases nursery pig maintenance energy requirements. J. Anim. Sci. 95(E-Suppl. 5):145. (Abstr.).

Iseri, V. J., and K. C. Klasing. 2013. Dynamics of the systemic components of the chicken (Gallus gallus domesticus) immune system following activation by Escherichia coli; implications for the costs of immunity. Dev. Comp. Immunol. 40:248-257.

Jing, L., R. Zhang, Y. Liu, W. Zhu, and S. Mao. 2014. Intravenous lipopolysaccharide challenge alters ruminal bacterial microbiota and disrupts ruminal metabolism in dairy cattle. Br. J. Nutr. 112:170-182.

Johnson, R. W. 2012. Fueling the immune response: What's the cost? Pages 211-223 in Feed Efficiency in Swine. J. Patience, ed. Wageningen Academic Publishers, Wageningen, the Netherlands. 
Kushibiki, S., K. Hodate, H. Shingu, T. Hayashi, E. Touno, M. Shinoda, and Y. Yokomizo. 2002. Alterations in lipid metabolism induced by recombinant bovine tumor necrosis factor-alpha administration to dairy heifers. J. Anim. Sci. 80:2151-2157.

Kvidera, S. K., E. A. Horst, M. Abuajamieh, E. J. Mayorga, M. V. Sanz Fernandez, and L. H. Baumgard. 2016a. Technical note: A procedure to estimate glucose requirements of an activated immune system in steers. J. Anim. Sci. 94:4591-4599.

Kvidera, S. K., E. A. Horst, M. Abuajamieh, E. J. Mayorga, M. V Sanz Fernandez, and L. H. Baumgard. 2017. Glucose requirements of an activated immune system in lactating Holstein cows. J. Dairy Sci. 100:2360-2374.

Kvidera, S. K., E. A. Horst, E. J. Laughlin, E. J. Mayorga, J. T. Seibert, M. Abuajamieh, M. Al-Qaisi, S. Lei, A. F. Keating, J. W. Ross, and L. H. Baumgard. 2016b. Effects of repeated LPS infusion on hematologic, metabolic, and intestinal histology parameters. FASEB J. 30:925.13. (Abstr.)

Lang, C. H., C. Dobrescu, and K. Mészáros. 1990. Insulin-mediated glucose uptake by individual tissues during sepsis. Metabolism 39:1096-1107.

Lanza-Jacoby, S., H. Phetteplace, N. Sedkova, and G. Knee. 1998. Sequential alterations in tissue lipoprotein lipase, triglyceride secretion rates, and serum tumor necrosis factor alpha during Escherichia coli bacteremic sepsis in relation to the development of hypertriglyceridemia. Shock 9:46-51.

Leury, B. J., L. H. Baumgard, S. S. Block, N. Segoale, R. A. Ehrhardt, R. P. Rhoads, D. E. Bauman, A. W. Bell, and Y. R. Boisclair. 2003. Effect of insulin and growth hormone on plasma leptin in periparturient dairy cows. Am. J. Physiol. Regul. Integr. Comp. Physiol. 285:R1107-R1115.

Liang, H., S. E. Hussey, A. Sanchez-Avila, P. Tantiwong, and N. Musi. 2013. Effect of lipopolysaccharide on inflammation and insulin action in human muscle. PLoS One 8:e63983.

Lohuis, J. A., J. H. Verheijden, C. Burvenich, and A. S. van Miert. 1988. Pathophysiological effects of endotoxins in ruminants. 1. Changes in body temperature and reticulo-rumen motility, and the effect of repeated administration. Vet. Q. 10:109-116.

Lumeng, C. N., S. M. Deyoung, and A. R. Saltiel. 2007. Macrophages block insulin action in adipocytes by altering expression of signaling and glucose transport proteins. Am. J. Physiol. Endocrinol. Metab. 292:E166-E174.

Maratou, E., G. Dimitriadis, A. Kollias, E. Boutati, V. Lambadiari, P. Mitrou, and S. A. Raptis. 2007. Glucose transporter expression on the plasma membrane of resting and activated white blood cells. Eur. J. Clin. Invest. 37:282-290.

Martel, C. A., L. K. Mamedova, J. E. Minton, M. L. Jones, J. A. Carroll, and B. J. Bradford. 2014. Continuous low-dose infusion of tumor necrosis factor alpha in adipose tissue elevates adipose tissue interleukin 10 abundance and fails to alter metabolism in lactating dairy cows. J. Dairy Sci. 97:4897-4906.

McGuinness, O. P. 2005. Defective glucose homeostasis during infection. Annu. Rev. Nutr. 25:9-35.

Memon, R. A., K. R. Feingold, A. H. Moser, W. Doerrler, S. Adi, C. A. Dinarello, and C. Grunfeld. 1992. Differential effects of interleukin-1 and tumor necrosis factor on ketogenesis. Am. J. Physiol. 263:E301-E309.

Mészáros, K., J. Bojta, A. P. Bautista, C. H. Lang, and J. J. Spitzer. 1991. Glucose utilization by Kupffer cells, endothelial cells, and granulocytes in endotoxemic rat liver. Am. J. Physiol. 260:G7G12.

Michaeli, B., A. Martinez, J. P. Revelly, M. C. Cayeux, R. L. Chioléro, L. Tappy, and M. M. Berger. 2012. Effects of endotoxin on lactate metabolism in humans. Crit. Care 16:R139.

Morey, S. D., L. K. Mamedova, D. E. Anderson, C. K. Armendariz, E. C. Titgemeyer, and B. J. Bradford. 2011. Effects of encapsulated niacin on metabolism and production of periparturient dairy cows. J. Dairy Sci. 94:5090-5104.

Murphy, K. 2012. Janeway's Immunobiology. 8th ed. Garland Science, New York, NY.
Myers, M. J., D. E. Farrell, C. M. Evock-Clover, M. W. McDonald, and N. C. Steele. 1997. Effect of growth hormone or chromium picolinate on swine metabolism and inflammatory cytokine production after endotoxin challenge exposure. Am. J. Vet. Res. 58:594-600.

NRC. 2001. Nutrient Requirements of Dairy Cattle. 7th rev. ed. Natl. Acad. Press, Washington, DC.

Neufeld, H. A., J. G. Pace, M. V. Kaminski, D. T. George, P. B. Jahrling, R. W. Wannemacher, and W. R. Beisel. 1980. A probable endocrine basis for the depression of ketone bodies during infectious or inflammatory state in rats. Endocrinology 107:596-601.

Palsson-McDermott, E. M., and L. A. O'Neill. 2013. The Warburg effect then and now: from cancer to inflammatory diseases. BioEssays 35:965-973.

Pennington, R. J. 1952. The metabolism of short-chain fatty acids in the sheep. I. Fatty acid utilization and ketone body production by rumen epithelium and other tissues. Biochem. J. 51:251-258.

Peterson, J. M., K. D. Feeback, J. H. Baas, and F. X. Pizza. 2006. Tumor necrosis factor- $\alpha$ promotes the accumulation of neutrophils and macrophages in skeletal muscle. J. Appl. Physiol. 101:13941399.

Plomgaard, P., K. Bouzakri, R. Krogh-Madsen, B. Mittendorfer, J. R. Zierath, and B. K. Pedersen. 2005. Tumor necrosis factor-alpha induces skeletal muscle insulin resistance in healthy human subjects via inhibition of Akt substrate 160 phosphorylation. Diabetes 54:2939-2945.

Raina, N., J. Matsui, S. C. Cunnane, and K. N. Jeejeebhoy. 1995. Effect of tumor necrosis factor-alpha on triglyceride and phospholipid content and fatty acid composition of liver and carcass in rats. Lipids 30:713-718.

Reeds, P. J., C. R. Fjeld, and F. Jahoor. 1994. Do the differences between the amino acid compositions of acute-phase and muscle proteins have a bearing on nitrogen loss in traumatic states? J. Nutr. 124:906-910.

Richardson, R. P., C. D. Rhyne, Y. Fong, D. G. Hesse, K. J. Tracey, M. A. Marano, S. F. Lowry, A. C. Antonacci, and S. E. Calvano. 1989 Peripheral blood leukocyte kinetics following in vivo lipopolysaccharide (LPS) administration to normal human subjects. Influence of elicited hormones and cytokines. Ann. Surg. 210:239-245.

Snavely, M. D., M. G. Ziegler, and P. A. Insel. 1985. Subtype-selective down-regulation of rat renal cortical alpha- and beta-adrenergic receptors by catecholamines. Endocrinology 117:2182-2189.

Taha, C., and A. Klip. 1999. The insulin signaling pathway. J. Membr. Biol. 169:1-12.

Taudorf, S., K. S. Krabbe, R. M. Berg, B. K. Pedersen, and K. Møller. 2007. Human models of low-grade inflammation: bolus versus continuous infusion of endotoxin. Clin. Vaccine Immunol. 14:250-255.

Toribio, R. E., C. W. Kohn, J. Hardy, and T. J. Rosol. 2005. Alterations in serum parathyroid hormone and electrolyte concentrations and urinary excretion of electrolytes in horses with induced endotoxemia. J. Vet. Intern. Med. 19:223-231.

van Miert, A. S., and J. Frens. 1968. The reaction of different animal species to bacterial pyrogens. Zentralbl. Veterinarmed. A 15:532543.

Vernay, M. C., O. Wellnitz, L. Kreipe, H. A. van Dorland, and R. M. Bruckmaier. 2012. Local and systemic response to intramammary lipopolysaccharide challenge during long-term manipulated plasma glucose and insulin concentrations in dairy cows. J. Dairy Sci. 95:2540-2549.

Vernon, R. G. 1992. Effects of diet on lipolysis and its regulation. Proc. Nutr. Soc. 51:397-408.

Waggoner, J. W., C. A. Löest, C. P. Mathis, D. M. Hallford, and M. K. Petersen. 2009a. Effects of rumen-protected methionine supplementation and bacterial lipopolysaccharide infusion on nitrogen metabolism and hormonal responses of growing beef steers. J. Anim. Sci. 87:681-692.

Waggoner, J. W., C. A. Löest, J. L. Turner, C. P. Mathis, and D. M. Hallford. 2009b. Effects of dietary protein and bacterial lipopolysaccharide infusion on nitrogen metabolism and hormonal responses of growing beef steers. J. Anim. Sci. 87:3656-3668. 
Wakayama, S., A. Haque, N. Koide, Y. Kato, E. Odkhuu, T. Bilegtsaikhan, Y. Naiki, T. Komatsu, T. Yoshida, and T. Yokochi. 2014. Lipopolysaccharide impairs insulin sensitivity via activation of phosphoinositide 3-kinase in adipocytes. Immunopharmacol. Immunotoxicol. 36:145-149.

Waldron, M. R., A. E. Kulick, A. W. Bell, and T. R. Overton. 2006. Acute experimental mastitis is not causal toward the development of energy-related metabolic disorders in early postpartum dairy cows. J. Dairy Sci. 89:596-610.

Waldron, M. R., T. Nishida, B. J. Nonnecke, and T. R. Overton. 2003. Effect of lipopolysaccharide on indices of peripheral and hepatic metabolism in lactating cows. J. Dairy Sci. 86:3447-3459.

Wannemacher, R. W., F. A. Beall, P. G. Canonico, R. E. Dinterman, C. L. Hadick, and H. A. Neufeld. 1980. Glucose and alanine metabolism during bacterial infections in rats and rhesus monkeys. Metabolism 29:201-212.

Wheelock, J. B., R. Rhoads, M. Vanbaale, S. Sanders, and L. Baumgard. 2010. Effects of heat stress on energetic metabolism in lactating Holstein cows. J. Dairy Sci. 93:644-655.
Williams, P. N., C. T. Collier, J. A. Carroll, T. H. Welsh, and J. C. Laurenz. 2009. Temporal pattern and effect of sex on lipopolysaccharide-induced stress hormone and cytokine response in pigs. Domest. Anim. Endocrinol. 37:139-147.

Yates, D. T., C. A. Löest, T. T. Ross, D. M. Hallford, B. H. Carter, and S. W. Limesand. 2011. Effects of bacterial lipopolysaccharide injection on white blood cell counts, hematological variables, and serum glucose, insulin, and cortisol concentrations in ewes fed lowor high-protein diets. J. Anim. Sci. 89:4286-4293.

Yuan, K., J. K. Farney, L. K. Mamedova, L. M. Sordillo, and B. J. Bradford. 2013. TNFo altered inflammatory responses, impaired health and productivity, but did not affect glucose or lipid metabolism in early-lactation dairy cows. PLoS One 8:e80316.

Zarrin, M., O. Wellnitz, H. A. van Dorland, J. J. Gross, and R. M. Bruckmaier. 2014. Hyperketonemia during lipopolysaccharide-induced mastitis affects systemic and local intramammary metabolism in dairy cows. J. Dairy Sci. 97:3531-3541. 